\title{
ISOLATION OF HELIOTRINE BY THE ION-EXCHANGE METHOD
}

T. T. Strakirov, S. T. Akramov, and S. Yu. Yunusov

Khimiya Prirodnykh Soedinenii, Vol. 3, No. 6, pp. 410-411, 1967

The alkaloid heliotrine has been isolated from the plants Heliotropium lasiocarpum [1, 2] and $\mathrm{H}$. dasycarpum [3]. The seeds and epigeal part of $\mathrm{H}$. lasiocarpum cause serious poisoning [4]. At the present time, heliotrine is the only agent in experimental medicine for obtaining a true picture of hepatitis and cirrhosis of the liver in experimental animals. We have developed a semiindustrial method for obtaining heliotrine from the plant $\mathrm{H}$. dasycarpum. The process of ex tracting the alkaloids from the plant material was investigated with various organic solvents, water, and dilute aqueous solutions of acids. The most acceptable results were given by extraction of the plant material with $1 \%$ hydrochloric acid. The adsorption of the alkaloids was studied on various cation-exchange resins (KU-1, KU -2, SBS, KB-4P-2, etc.). Good results were obtained with the use of KU-1 resin.

Extraction was carried out with $1 \%$ hydrochloric acid in $250-l$ extractors containing $50 \mathrm{~kg}$ of comminuted epigeal part of the raw material. Five decantations were carried out, at four-hour intervals. The acid extract of the alkaloids was passed through a battery of adsorbers consisting of three columns ( $\mathrm{d}=0.15 \mathrm{~m}, l=0.4 \mathrm{~m}$ ) each containing $2.0-2.2 \mathrm{~kg}$ of $\mathrm{KU}-1$ ion-exchanger in the $\mathrm{H}$ form with a moisture content of $40-50 \%$. The rate of adsorption varied from 4 to $9 l / \mathrm{hr}$.

The desorbents used were ammoniacal solutions of ethanol and methanol with various $\mathrm{pH}$ values, a $1.5 \%$ solution of ammonia in $85 \%$ ethanol, and an alkaline mixture of chloroform and ethanol $(1: 1) .95 \%$ ethanol saturated with gaseous ammonia to pH 5 proved to be a good desorbent. The ethanolic solution obtained from the adsorbers was evaporated in vacuum to dryness. The yield of combined alkaloids was $0.90-0.92 \%$ (of the weight of the raw material).

To isola te the heliotrine, the total combined alkaloids were dissolved in $15 \%$ hydrochloric acid, and the N-oxide forms of the alkaloids were reduced with zinc dust. Then the mixture was made alkaline with ammonia and extracted wi th chloroform. The chloroform extract, after drying with potassium carbonate, was distilled in vacuum to dryness. Acetone reatment of the residue gave crystals of heliotrine with mp $125-126^{\circ} \mathrm{C}$ (from ace tone). The yield of heliotrine was $0.40-0.45 \%$ (of the weight of the air-dry raw material).

\section{REFERENCES} 1936.

1. G. P. Men'shikov, Ber., 65, 974, 1932, 66, 875, 1933, 68, 1051, 1555, 1935; Izv. AN SSSR, 969, 1802,

2. S. Yu. Yunusov and G. P. Sidyakin, DAN UzSSR, no. 1, 3, 1950.

3. S. T. Akaramov, F. Kiyamitdinova, and S. Yu. Yunusov, DAN UzSSR, no. 4, 30, 1961.

4. Proceedings of the Department of Pathological Physiology, Questions of Regional Pathology [in Russian], Tashkent, 1956.

27 May 1967

Institute of the Chemistry of Plant Substances AS UzSSR

UDC $547.944 / 945$

\section{STUDY OF. THE ALKALOIDS OF THE FAMILY BORAGINACEAE}

F. Kiyamitdinova, S. T. A kramov, and S. Yu. Yunusov

Khimiya Prirodnyk Soedinenii, Vol. 3, No. 6, pp. 411-412, 1967

Heliotropium olgae Bge. The plant was collected at Tashkumyr in the Andizhan region of UzSSR in the flowering and incipient fruit-bearing stage (10 October 1957 ). The epigeal part yielded $0.85 \%$ and the roots $0.32 \%$ of combined alkaloids. 